\title{
Loss of Chromosome 17q
}

National Cancer Institute

\section{Source}

National Cancer Institute. Loss of Chromosome 17q. NCI Thesaurus. Code C36544.

A cytogenetic abnormality that refers to the loss of all or part of the long arm of chromosome 17 (17q). 